\title{
Odeon Publishing: The Island of Freedom
}

\author{
VRATISLAV KOZÁK*
}

Nakladatelství Odeon: Ostrov svobody

\begin{abstract}
Normalization period is a unique time in Czechoslovak history that is almost everywhere presented as a time when the socialist regime used its position of power to take back all production and culture including publishing houses. Odeon was a well-known entity at that time and looking back at the editorial and publishing plan from the said period it sometimes seems as if Odeon was partially untouched by the repressions. It is important to concentrate on everyday life in the publishing house while trying to find out how Odeon and its editorial team managed to publish so many books that almost nobody expected to see in a Czechoslovak bookshop. The topic of state censorship, as well as a very specific topic of "covering" the banned authors, will be the central focal point of this article.
\end{abstract}

Keywords: Odeon; publishing house; covering; literature; translators

DOI: $10.14712 / 23363525.2019 .18$

\section{Odeon in General}

Normalization was a specific period of Czechoslovakian history as it is considered to be a period of forced restoration of the conditions prevailing in Czechoslovak society before the so-called Prague Spring period. The term itself comes from a document called the Moscow Protocol which was signed on August 27th, 1968. Eva Forsová would call the scenario the typical totalitarian version of normalization, meaning that in this case the change is forced upon the society by the regime [Forstová 2013: 12]. When looking back at this period of history people tend to imagine these times in pretty black and white style, often forgetting all the shades of grey in between. It may seem easier for everybody to consider the communist regime to be the "only one to blame". It is important to realize that it was not a big struggle with the regime on one and the people on the other side. When speaking about repressions or censorship itself then the dictatorship could force such censorship only with the participation of a pretty vast number of people [Šámal 2015: 1099]. That means that normalization period was not the most pleasant one and many people are to blame for problems of this time but at the same time there were others (sometimes even members of the regime itself) who were trying to remedy these problems. Apart from that, it was also a period when a large number of high-quality books from all corners of the world were published. Czechoslovakia, and especially the Czechoslovak public, managed to keep up with the world trends and it cannot be said that they were somehow culturally

\footnotetext{
* Mgr. Vratislav Kozák, Katedra historické sociologie, Fakulta humanitních studií, Univerzita Karlova, U Kř́íže 8, 15800 Praha 5. E-mail: vratakoz@gmail.com
} 
lagging behind thanks to that. The main reason for that was the state publishing houses. There was one among these publishing houses which surpassed all the others with its production, the richness of its editorial plan, and the highly extensive reader base, and that was Odeon. If someone has several books from the mentioned period of Czechoslovak history, then it is almost impossible for Odeon's books not be among them. Over the years Odeon has developed a high-quality reputation, thanks to which the name of the publishing house exists as a trademark up to this date. In 1999, the Euromedia Group publisher bought this well-known brand and has kept it ever since. The article is, for better understanding, divided into two parts. One part is about Odeon publishing house in general, explaining the history of Odeon, describing the hierarchy of Odeon's employees, an everyday process in the publishing house including acquiring manuscripts and preparing a future editorial plan. The second part is about the political influence of a socialist regime over the mentioned everyday process and work-flow in the publishing house. Here some specific topics need to be covered. One of them is the everyday presence of the regime in the publishing house and how did employees deal with that. Then very important topic is interfering into the editorial plan by the state through censorship and similar concepts. And finally, the last topic will be a pretty unique phenomenon called covering or in other words a means how to protect the banned authors from being punished by the state while doing their job. The main goal is to show that state power had a constant presence but the employees managed to find their way around it in order to keep the reputation of Odeon alive as being one of the best-known publishing houses with an imposing range and variety of titles to offer.

\subsection{Odeon's History}

Publishing house was founded in January 1953 on the basis of other famous publishing company called Družstevní práce and it was originally named Státní nakladatelství krásné literatury, hudby a umění (National publisher of literature, music, and art) or SNKLHU in short [Steinová 2007: 192]. With the foundation of Státní hudební nakladatelství (National musical publisher) in 1961 music was separated from SNKLHU and finally from January 1st, 1966 onward the SNKLHU assumed the name Odeon. The name followed up on another publishing house called Odeon, ${ }^{1}$ which was shut down in 1949 [Halada 2007: 241]. But the true origin of the name Odeon comes from the Greek word "odeion", meaning an ancient place of cultural and artistic nature.

Publishing house was located in Prague's centre on street Národní trrída no. 36 in the former House of Applied Arts, where Odeon owned several floors and the publisher stayed at this location right until 1994. The Readers club, established in 1953, was also a part of Odeon. Odeon still as SNKLHU at that time took over the directories of newly defunct clubs and merged them together to create an impressive reader base. The Readers club

1 On March 24, 1949, the National Assembly adopted Act No. 94/49 Coll., on publishing books, music and other non-periodical publications. It ended a long era of private publishers in Czechoslovakia. The publishing houses gradually became the property of political parties, social organizations, unified trade union organizations, top cultural, economic, sports, etc. cooperatives and societies obligatorily associated with the National Front or those that remained in the hands of the state. Permits were obtained only by ideologically reliable subjects [Halada 2007: 7-8]. 
gained during its existence the largest membership base of impressive 400,000 members. Odeon also owned its own bookstore located in Prague on street Na Florenci and used many other pick-up spots. Since 1956, the publishing house published a bimonthly magazine called Světová literatura (World Literature), dedicated to contemporary prose and poetry. The sole purpose of this magazine was to familiarize Czech readers with foreign literature. In the sixties, a more prominent publishing concept has been formed, which has tried to limit governmental direction from the state. On April 3rd, 1968, Publishers and Bookstores demanded that a progressive publishing law should be issued as they also opposed the directive management of the book culture by the state, which was temporarily revoked and subsequently restarted with the coming of normalization. They also demanded the abolition of censorship and established the Union of Czech Publishers and Booksellers. By 1992 Odeon underwent an unsuccessful reorganization, and was put into liquidation in 1994. Subsequently, Odeon underwent other several unsuccessful attempts to reorganize and privatize. After some unsuccessful attempts to revive Odeon, in 1999 the company brand has been bought by the publisher Euromedia Group, which owns it till this day [Přibáň 2014: 279-281].

Odeon published about 150 titles per year and for the entire period of its existence, it published around 8000 titles. Publishing house received many awards, such as the National prize for authors, translators, and artists at various fairs worldwide. The original task of publishing original fiction literature (mostly classical) and translations (classical and contemporary), later changed and Odeon was focusing almost exclusively on publishing translated contemporary literature from all continents, including writer's dictionaries, essential works of literary science and aesthetics, art books, reproductions, and art postcards. Odeon was overall the largest producer of translated literature with high quality published titles (even from such unique languages as Persian and Inuit) [Halada 2007: 242].

\subsection{Odeon's Daily Process}

The everyday process of each publishing house is quite a complicated, but a perfectly complex process. There is a well-defined hierarchy between departments and between employees themselves, as is often the case for similarly sized companies. Publishing house's personnel composition may differ from case to case, but even the smallest publishers must have three key individuals - the business owner, editor and graphic designer. Given that the Odeon was a national company, thus there can't be any other owner, excluding the state itself. Owner's office was represented by a man who was appointed to the position of director. Head publisher is a title that is used for the specific person who is actually the owner himself. Therefore, in the case of the Odeon, we can only talk about the director. Director is the man who makes all the decisions within the publishing house. The biggest amount of work, however, always falls on the editor. If there are a lot of them, then an editor in chief is chosen, who stands above the individual editors and is a direct subordinate of the director [Pistorius 2003: 112].

In case of the Odeon, there was a problem because the directors were de facto representatives of the state, which means that they acted as supervisors and they have been paying attention to the activities of the rest of the staff, which they regularly reported to the government. This implies that the director had often absolutely no idea what a good 
publisher should do and the responsibility for the publishing house often fell on the head of the editor in chief. A longtime editor in chief Josef Čermák had this to say in the matter:

I was removed from office at the end of the seventies and I became the main literary editor. I have been doing exactly the same stuff as before because directors and a new editor in chief had no idea what to do. The director was sitting behind his desk all the time, smoking his pipe and waiting for someone to come for a visit or he just went off to the city. So it was up to me to do almost everything as a main literary editor. [...] It was too much for the directors - they were just puppets. [Čermák 2014: 8-9]

It is evident here that the quality level of Odeon depended on benevolence and effort of people like Josef Čermák and others around him.

Čermák was an indispensable man for the Odeon due to his foreign contacts, linguistic and cultural education, and his good knowledge of the market. The position of the director was a much easier one with better pay; therefore, there was a far greater interest in the position of the director as compared with the position of editor in chief. According to Čermák all the main high quality and hardworking employees in editorial staff were people, that weren't members of the Communist Party. That sure is interesting but the explanation can be pretty obvious. After the year 1968 Communist Party of Czechoslovakia expelled many highly educated members of the Party within the so-called "Party purges". 2 That means not many members of the Communist Party remained that would be qualified enough for the position of editor in chief. This explanation cannot be used for all the cases but it is definitely worth mentioning. Since the directors were mainly appointed to the Odeon as supervisors of state power, most of the activities they should have been dealing with were transferred to their direct subordinates, meaning the editors-in-chief. An Editor-in-Chief is a person who manages the entire editorial office and is responsible for its day-to-day work. He is the head of the editorial team. The main task of editor-in-chief and his team is the acquisition of new titles and their subsequent editorial preparation. As a result, editors need to have a pretty clear idea about the current market options to know what is popular among people, and also to have an overview of everything new around the world. Part of his work is also to do the editing of the books themselves, which means checking all the information. This, especially in the case of the factual literature, requires the editor to have a perfect overview and knowledge in the field. In addition, the editorial staff of the book along with the editor-in-chief has also the role of a stylistic and spelling checkers. That is why the editor needs also an excellent knowledge of the native language or, in the case of foreign books in need of translation, also some foreign language. Only this way it will be possible to ensure that the translation is of high quality and as faithful as possible to the original idea [Pistorius 2003: 110-112]. So editor could also serve as an official translator for the publishing house but in the case of Odeon, the situation was a little more problematic. According to Mr. Čermák per the rules or regulations of the Odeon, all internal editors could serve in the position of translators also if there was nobody else available and even then they received much lower pay for the actual translation. Therefore, high-quality

2 So called Party purges are a well-documented topic of the history of Czech Communist party and more information can be found in basically all scientific literature focusing on the mentioned topic like for example [Rataj-Houda 2010] or [Vaněk 2006]. 
translators like Čermák ended up translating the book for different publishing houses instead [Čermák 2014: 8].

\subsection{Acquisition of Manuscripts}

The overall process of issuing new books as part of the publishing house begins with the acquisition of a manuscript for a future book. It is the task specifically for editors to be constantly searching for new titles or authors, based on domestic demand, experience from abroad or their own gut feeling. The editor should have a good enough knowledge of the market, both domestic and foreign, that he should be able to determine which title has a better chance of succeeding than the others. The editor must be able to encourage the creation of titles that could be successful in the domestic market. The editor should, therefore, be culturally and literary educated person who himself knows the value of many old and classical literary masterpieces and is able to determine which titles should be brought back to the market for modern readers to enjoy. The problem of censorship goes hand in hand with this as it is mainly manifested in these classical masterpieces. In the case of new and modern books, there are always ways to meet the requirements of state and ideological terms, but in case of a variety of literary masterpieces that went back to the press, no one could simply change them [Pistorius 2003: 106]. Čermák talked about the process of acquisition full of fond memories. He said that he was having a cup of coffee with many other editors and they recommended some new titles to him and he did the same for them because every publishing house was mainly focused on a certain type and genre of books and this way the editors could help each other without taking each other for a competitor. When talking about foreign publishers Čermák said:

We had a connection with dozens of publishing houses. I knew these people, because, although I was never a member of the Communist Party, I traveled abroad a lot to many international book fairs. I was sometimes accompanied by one of the directors, who usually could not speak a single word in another language. Thanks to that I had over the years many, many excellent friends from abroad. [Čermák 2014: 3-4]

According to translator from Odeon, Josef Forbelský, it was the Prague Spring and the overall events around the invasion of the Warsaw Pact army in 1968 that made Czechoslovakia so famous around the world that many foreign publishers wanted to visit Prague just to find some interesting Czechoslovakian books that they could translate and publish in their own countries [Forbelský 2013: 296-298]. One of the first insights into Odeon as an "island of freedom" comes again from the editor in chief Josef Čermák when he talks about forced publications.

We weren't forced to publish a specific book, you know. But then came a time when we had to do something because we couldn't avoid those culturally-political things. For example, in the year 1975, we received an order to publish an edition called The Selection of the Best pieces of Soviet literature, on the occasion of the 30th anniversary of liberation at the end of Second World War. So what, we chose only the best books that we could - Šolochov for example. I wouldn't say that we considered ourselves to be some form of resistance against the regime but you wouldn't find an editor that would sign his name under some bad book. [Čermák 2014: 13] 
That is actually a great example of how, in this case, editor in chief, can bend the rules in order to achieve a specific goal. The censorship rules and regulations had many "blind spots" which allowed the right people to find some exceptions, place for negotiation or even the mentioned opportunity to bend the valid rules [Š́mal 2015: 1106]. Censorship itself is an important topic. It is one that cannot be completely understood without mentioning the political influence on everyday life in Odeon.

\section{Political Influence}

There is no easy answer to the question if politics had a big influence on Odeon. Politics in the everyday operations of the publishing house certainly had some sort of influence in many areas that need to be properly analyzed. So it is important in this chapter to deal with the issue of censorship, banned authors, "coverage", informers, and various other restrictions by the state. Careful analysis of these various areas and problems will then provide a proper insight into the situation, which shows to what extent the government's policy should affect the Odeon as an institution and its staff. Michael Wögerbauer in the introduction to the book Nebezpečná literatura? Talks about how the first newspaper article by Karl Marx was actually not about the class conflict but about censorship. Marx calls the censorship "official critique" and mentions that it is not operating properly. He thus opens an important question if that is due to bad censorship rules or incompetent censors themselves. After that he immediately offers his take on the problem, mentioning that wise government would never renew any bad law or rule which means that the blame is on the side of the censors who are either truly incompetent or they break the rules knowingly [Wögerbauer 2012: 7]. Certainly not everybody can agree with such a statement but it is very important to think about the possibility that it does not have to be this "power" in a form of state or regime that can be at the head of censorship but even the individual censors $^{3}$ can push the limits of what is acceptable not only for the state but also for themselves. Wögerbauer also talks about another important fact that censorship is not always a secret strategy of someone in power but it can also become a well-known concept for the whole society [ibid: 13]. When that happens authors will learn how to edit their own manuscripts because they very well know what they should edit out and vice versa which sentences should be included in order for this book to be published. The same goes for the reader as whenever the reader gets used to the censorship in the books he can easily anticipate the specific parts, like those added just so the book can be published, and he can skip them while reading the book. In this way, both sides will learn how to cope with censorship as an everyday concept. Michael Holquist goes even further when mentioning that censorship actually forces the reader to analyze and critically think what he is reading [Holquist 2012: 103]. That is the reason why there are two ways how censorship can be understood. There is a more old fashioned way of understanding censorship when the term means basically a number of specific rules and regulations, enforced by a person of some form of official standing in society (sometimes even working for specific censorship organization). Then the second way or concept is known as new censorship and the baseline here is that

3 Meaning people appointed by the regime to supervise state-wide censorship. 
censorship in some form is everywhere. It is not enforced only by a selected group of people but by habits, laws, etiquette, etc. [Müllerová 2012: 221-224]. Even auto-censorship plays a significant role in this concepts because through the mentioned habits, laws and other things people tend to censor themselves even before actually speaking or writing anything. When speaking about censorship it is therefore important to diversify between these two concepts.

\subsection{Politics in Odeon}

Odeon was a national publishing house which means that its policy was subjected to the ideology of the state. In the early years of "normalization" period, the director of Odeon was Jan Rezáč, who in his time managed to unify the rules of state ideology and a certain level of expertise in the publishing and literary field. After him, none of the directors had the ability to do something like that. Řezáč can be considered an exception to the rule regarding his position as a director partially thanks to the fact that he started as an editor in chief and as such gained all his experience [Přibáň: 2014: 281]. Translator and editor Marie Janů remembers Jan Řezáč and how he formed a link between politics and publishing profession:

Odeon belonged under the Ministry of Culture. Odeon had it the worst. There were some people afraid for their jobs, so - even though it was not too much of a partisan company - they had to keep an eye on one another. Director Jan Řezáč was indeed the exceptionally well-read man that knew what was good and what wasn't but he had to publish books, where he knew that they will go through censorship. [Rubáš 2012: 134]

Řezác was a longtime member of the Communist Party so he knew very well what the political boundaries were at that time. But at the same time, he loved literature so he did his best for Czechoslovakian culture. Other directors were much worse than him as they did not share his qualities.

The events of 1968 caused the departure, whether voluntary or not, of many members of the editorial staff from the Communist Party. A problem arose for the state policy within the Odeon in the form of an ideological vacuum, and so it was necessary to act. Josef Čermák was still editor in chief and he was surrounding himself with like-minded people. Thanks to that the whole editorial office transformed itself into an "island of freedom". The term "islets of freedom" refers to certain places, organizations, groups and so on, that operated either more or less noticeably in the boundaries of the totalitarian state while not truly obeying its rules and laws [Vaněk 2002: 9-10]. They all had a much smaller influence on the Czechoslovakian nation in comparison with Odeon and that is why it should not be called an "islet" but an "island of freedom" instead. Editor Josef Forbelský recalls other changes when talking about the breakthrough year of 1968: "Some new faces began to appear in Odeon and I didn't know any of them because they belonged to the former communist establishment. Former ambassadors and section chiefs now wanted to at least provide proofreading services" [Forbelský 2013: 314]. As Forbelský clearly states many high ranking officials from the Communist Party were demoted after the events of Prague Spring so they were looking for a place where they could make use of their knowledge of foreign languages. Odeon was one of the better options for them. 
Editor in chief Josef Čermák mentioned yet another thing that was typical for the influence of politics in Odeon and that was an obligatory use of Soviet terminology in the editorial office and publishing house as a whole.

There were just too many people for my taste and I mean not in the editorial office itself but in some of the other departments - all sort of functions. Higher ups thought that this was their Soviet model which was in full effect so nothing ever got out. The editor was supposed to be there to check what every translator or author wrote and so on. We took this and remade it somewhat over the years and from that we developed, how to say it, much more effective work with handwriting, etc." [Čermák 2014: 7]

Again another good example of what "island of freedom" means. Čermák and people around him in the editorial office took all the orders from government and either found the way around them or adapted them in the way that the cultural contribution of Odeon remained intact. Čermák took it upon himself to be that connection between government politics, embodied in the position of director, and day-to-day work in the editorial office.

Since the Odeon directors were people that the government considered being safe and proven, their only job was to supervise everybody else. The editors in chief had to defend every single decision of the editorial office. They had to visit regular meetings of the Central Committee of the Czechoslovakian Communist Party where they had to defend various books, afterwords or mere sentences, which were seen as harmful when compared with state ideology. Every "ideological fault" of course poorly reflected on the editorial staff [Rubáš 2012: 76]. The whole editorial plan had to be pre-prepared two years before the actual publications saw the light of the day. The reason being that the ministry needed enough time to go through each editorial plan and check every book accordingly. But as time progressed the situation was changing and the main focus of the ministry was on the auto-censorship. Authors and editors were informed in great detail about what was "not in the best interest of the regime" and they were expected to check the individual books themselves in order to delete or edit such problematic phrases or statements [Šámal 2015: 1117-1118, 1178]. Another unique look at the situation and the working conditions in the editorial office had a former Odeon editor Jarmila Fialová:

We in the editorial office knew each other pretty well at that time. We lived together through the difficult years of 1968 a 1969 and there was probably not a single traitor amongst us. We talked openly and believed each other. We suffered under the effects of normalization period but just on the inside, not among us. [Rubáš 2012: 76]

People in the editorial office trusted each other because almost every one of them either stepped out of or was let go from the Communist Party after the events of Prague Spring. However, many of them were irreplaceable for the Odeon so instead of being fired they were either demoted or without the chance of future salary increases.

There was a sort of working relationship between Odeon and Charles University, namely the Faculty of Arts in Prague. The faculty was under the influence of state politics and ideology a lot more than Odeon and therefore many faculty personnel quit their job and began working in the publishing house in various positions. Not only that but Odeon took in even some people that were actually fired from the faculty. Even many writers banned by the regime of the state used to visit Odeon from time to time and thanks to that 
Odeon's ambiance sometimes resembled that of a literary salon [ibid: 94]. A long-time Odeon translator, Věra Dvořáková called Odeon “almost a resistance nest” [Šustrová 2008: 49]. People at Odeon preferred quality of their production over political quotas and rules. Those remained a worry for the editor in chief who was under constant supervision of the director, but it hardly affected the editorial office itself.

\subsection{Interfering in the Publishing Plan}

The publishing house basically acts as a cultural, social and economic institution. Publishing house can focus on different goals - major and minor - which ultimately means that some publishers will focus on non-periodical literature and others won't. At the theoretical level, the goals of a publishing house are expressed by editorial or publishing plan [Halada 1993: 34]. Odeon had, like all other publishers, publishing schedule through which its aim was clearly defined within the literary culture. The actual publishing plan reflected a vision of individual directors or rather, in this case, the editors in chief within the publishing house. Every new editor in chief could somehow intervene in this vision, thus, to enhance it or conversely to narrow it a little. But he also had to respect a kind of cultural tradition of Odeon to a certain extent. It was a tradition set by his predecessors.

All the big publishing houses operated almost solely on a base of publishing plans. Although it could happen from time to time that something was published outside of the publishing plan, it was not so common and it usually happened for reasons of political or commercial nature. Editions, which are the basis of a publishing plan, are basically an expression of publishing creative intent, meaning current and the future one. A reader's club is the broadest concept in the context of editorial work. Reader's clubs were in terms of editorial activity usually conceptually very well conducted, affordable, typographically processed by prominent artists and designers, ${ }^{4}$ as well as sought out by readers resulting in a high outlay. The Odeon's Reader's club was one of the largest in the country [Halada 1993: 96-99]. Each edition has its meaning and its function. These functions can be divided into two major groups - one targetting the readers while trying to appeal to their collector-type behavior by sharing a similar design of a book's cover between all the books in one edition. The other serves a completely different purpose and that is a specific stabilization for the editorial office as each edition gives them pretty clear boundaries for choosing the next book that can be added to the edition [Pistorius 2003: 135-150]. For the period of its existence Odeon published countless editions.

The Odeon's Reader's club was well-known for its large membership base. The club was founded on February 1st, 1953 and it was managed by the editorial board from the very beginning. Odeon, still as a SNKLHU at that time, took over the directories of already defunct clubs which helped to build a new readership. Since the early sixties, Reader's club's membership was around 250,000 people. The actual publications of Odeon were shipped to members of the club at a discounted price. Odeon also established dispensing locations in Prague, Brno and later in some other bookstores. After the demise of Odeon,

\footnotetext{
4 Covers of some books are considered to be of the highest quality and some of them were later used as a template for future design. For anyone interested in this topic there is a book availabe that have been published in the year of 2016 and it covers the evolution of Odeon's book covers throughout the years [Klímová 2016].
} 
it was the Book club that took over the entire database of club member's addresses. The Reader's club was equally as subjected to state politics as to the requirements of its readers. Therefore some sort of compromise had to be found. As the Readers' Club is concerned there were efforts to comply with the various limits set by the state, whether it was the amount of paper used per year, outlay or cost of books, but on the other hand, Odeon had to satisfy its customers and had to maintain its publishing plan sufficiently diverse enough that every member of a large membership base could choose a title that suited him. Former editor in chief Josef Čermák regrets still to this day the eventual loss of that large membership base that Odeon had. Per him the biggest outlay Odeon ever had were two hundred thousand copies of the book Mary Stuart from Stefan Zweig [Čermák 2014: 4]. Editor and translator Jiří Našinec remembers a kind of unique way how the Reader's club was used to secretly publish a book from banned Romanian author Mircea Eliade:

I was wondering how to push him [Eliade] through because that wasn't a simple task at all. He was labeled as a "vicious emigrant" and additionally as a follower of far-right politics. I managed to do it in the year 1984 under Odeon's Reader's club where Odeon was publishing always five novels from a single nation at once. So thanks to that I managed to include Eliade into Five Romanian novels and hide his book behind a neutral name. Once his book was out in the open, another publisher could then always refer to it when they wanted to publish some of his other titles. [Šustrová 2008: 199]

A traditional Odeon's edition Five novels was used to secretly publish a banned author, that is just another example of Odeon as an "island of freedom".

It is therefore obvious that state politics at least attempted to strongly intervene in the publishing plan. Fully compiled publishing plan had to be handed over to the Ministry of Culture for a regular check-up, which was sometimes extensively thorough. Odeon had a deadline for handing over the finished version of the publishing plan and the whole editorial office worked really hard while trying to perfect it so nothing would be crossed out of it. Publishing some titles required a good pre-prepared defense from the editor in chief. Čermák also didn't forget all the assistance from external experts, whose authority was officially recognized, especially between members of the Communist Party, and who risked a lot by helping and defending him [Rubáš 2012: 35]. All the editors knew pretty well which books could pose a problem so when there was a title without any chance for success they didn't include it into the publishing plan as they knew it would be a waste of their time. But the final decision was in the hands of editor in chief.

Politics, therefore, interfered with the publishing plan and Ministry of Culture had the right to censor it, which could easily mean that several books have been completely deleted from the list. The term "censorship" was almost never used officially as it was considered to be a pretty negative sounding word. Therefore, it can be said that even the word "censorship" itself was censored. These regular check-ups of publishing and editorial plans along with the changes made were not presented as censorship but as an effort to achieve more professional culture management in the country [Šámal 2015: 1104]. When talking about the political censorship there are some areas or precise points that were to some extent problematic for the regime and should be defined. Defining them is not as much of a problem as someone might expect. Every editor knew very well what exactly is undesirable for the regime and the problem was solved either by that same editor (self-censorship), 
or at least some form of adequate defense had to be prepared. According to Čermák, the whole editorial office had two big constraints from the regime, one being a criticism of communism and the second was morality. There's no need to explain why some form of criticism of communism was banned. Any of its blatant forms were simply forbidden and any book that would focus its main intention on that form of criticism had no chance to pass through state censorship. The question of morality was not so much of a regime problem but more like a cultural problem. Profanity, vulgarisms, and slang were the issue here. Thanks to that Odeon had problems with authors like Jack Kerouac and some others that they could not publish at that time. The only solution was to let some people who were trustworthy for the state write a foreword where they, through strong moralizing, explained what in the particular is wrong in the book [Čermák 2014: 6].

Similarly, a difficult situation awaited a book, whose author was a man rejected by the regime. These political boundaries applied to a book's author, rather than the book itself. The book could potentially have a big problem with state censorship even though it was perfectly ideologically safe so to speak. The editorial office then defended itself by the very fact that the book itself does not violate either one of the main boundaries, but more often than not it was not valid because the regime refused to see any book from a banned author on sale. This issue was more problematic, because while in the context of book's content the editors themselves were able to guess what could bother the state representatives but in the context of authors, it was not so easy. On one hand, Odeon had some form of a list of banned authors but that list could always change. Authors weren't the only ones that could be on the list because the same applied to translators. The government paid close attention to many translators and some of them were also on the list of banned authors. That meant they not only couldn't publish their own books but they also couldn't translate any other books. Editor and translator Josef Forbelský talked about how he was in charge of translating a book from Spanish Baroque poet Luise de Góngory y Argote together with translator Josef Hiršal. But Čermák was afraid as Hiršal had a label of a banned author/ translator by the regime and Čermák knew that if they wanted to publish that particular book they might need some other translator to do it. In the end, Forbelský was not needed to cover for Hiršal and the book came out just fine [Forbelský 2013: 307]. These situations were not nearly as unique as they might sound and because the ending could potentially be a lot different than in this case it all then led to the emergence of a specific phenomenon called "coverage".

A long-time translator Olga Krijtová draws attention to the fact that state censorship operated on both sides. She said there were many cases when the foreign publisher didn't allow some of their books to be translated into Czech from an ideological standpoint. Some states or even authors themselves did not want their book published in socialist Czechoslovakia [Šustrová 2008: 172-173]. It is important to realize that just as local propaganda to some extent "demonized" the West, the West did something similar in relation to the East. This political intervention of another country to our literary culture did not have to be only from the side of hostile states. On the contrary, it was very often countries with which Czechoslovakia had a good relationship. In these cases, the reason for the censorship was the author. If it was an author who was banned in their own country, the local government asked all the friendly countries if they could do the same and refuse to publish books from that particular author. Such was the case with Cuban author Lezama Lima for 
example, whom Cuban revolutionaries did not accept. Translator Josef Forbelský translated Lima's book and Odeon wanted to publish it but it was the Cuban government, not the Czechoslovakian one, that was blocking the whole ordeal. The book was lying on the shelf for more than ten years before it was finally published [Forbelsky 2013: 326]. Another topic that immediately comes to mind is the ratio between "western" and "eastern" literature. When Josef Čermák was asked about this, he said that it depends on which decade we are talking about. So when talking specifically about the normalization period he said that until the beginning of seventies French literature was the most popular in Czechoslovakia, then came a boom of English and American literature. The government took notice and ordered Odeon an even ratio between "western" and "eastern" literature. That was not such a big problem because there were a lot of really good books from eastern authors but they did not sell very well. Therefore people from the editorial office came with a little trick and they started publishing eastern literature in much smaller outlays while still maintaining the equal ratio. To hide this fact and to please the government Odeon was publishing those books from eastern authors with wonderful graphic designs so the books looked impeccable. That, however, didn't last long and soon enough government found out about that simple trick and ordered Odeon equal outlay numbers. That was a lot more problematic. Editorial office immediately came with yet another plan. Čermák defended many western authors and said that they are progressive, members of the left-wing political party or they are engaged in some sort of a peace movement. Thanks to that some western authors were not seen as problematic in the eyes of the Czechoslovakian government anymore.

Books with religious themes were also a big problem for Odeon because religion was utterly undesirable for the regime. Editor and critic Dušan Karpatský, for example, had to fight this limitation when trying to publish a book called Fables and Fairy-tales:

The author, Ivana Brlićová Mažuranićová, was deeply religious. So in her stories, the word "God" appears many times. Publishers had big problems with that and wanted to eradicate the most beloved God. Then I came to the salvific idea. I said: Look, we will write his name with a small letter "g". It'll not hurt him and it won't be so noticeable. So in this book, we eventually have a god with a small g, but we got him there wherever the author wanted. [Šustrová 2008: 139]

Moral boundaries weren't for editors nearly as big a problem as the political ones because it was all about vulgar language or descriptions of intimate scenes that bothered the government. It was not too much of a problem for the editorial board of Odeon because these passages could be somehow modified or omitted entirely from books during translation. It usually didn't hurt those books at all and at least they could be published without any major problems. If some really bold book with vulgarisms or erotic scenes was printed before the government had a chance to stop the publishing process then it was said that the book was officially for a professional audience that needed it for educational purposes. Each customer had to have a special confirmation sheet to prove that it is indeed the case and only then he could buy that specific book [Rubáš 2012: 104-105].

Odeon had also big problems in the context of Czech literature, which for someone may come as a surprise. Odeon in fact due to dissension and rivalry with a publishing house called Czech writer lost its entire Czech editorial office that was focused only on Czech literature. Czech literature in the Odeon thus lost its individual status and could be published solely as part of world literature. Therefore Odeon became a publishing house 
focusing primarily on translations of foreign literature. This situation had a strong impact on various Czech authors who wanted to publish their books within Odeon. Josef Čermák was not a big supporter of this decision and had his share of problems thanks to that:

Then I received a letter from the poet Jaroslav Seifert, in which he offered Odeon the rights to publish the memories of his friends. He told me that he has his reasons for not wanting to publish it within Czech writer and that he has confidence in me and Odeon (he was a friend of my father in law from youth). We agreed immediately and I then sent my secretary Ilonka Lukešová to pick up the manuscript at the main post office. But those people at Czech writer publishing house learned all about it and immediately informed the Central Committee with the overriding requirement that the book has to be published by them. They went into a fight with heavy calibers [...] Fierce and unequal battle was unleashed and we lost. We had to hand over the manuscript. [Rubáš 2012: 33-34]

So even when the author himself specifically said that he wanted Odeon to be the publisher of his own book, the government intervened and didn't allow it. The author had to accept the fact that his book will be published elsewhere or he would not see it published at all. Odeon, therefore, had as big problems with the Czech literature as with the foreign one, in some cases even much bigger.

\subsection{Covering}

After analyzing political influence in Odeon, it's time to look at yet another example of why Odeon can be called the "island of freedom" and that is the phenomenon called "covering". When speaking about the political interventions and noticeable influence of state ideology on Odeon, then the topic of "covering" cannot be excluded. The topic of banned authors was mentioned several times. Covering phenomenon is, however, generally related to the translators. While the normalization period was underway, many translators found themselves on the list of banned authors. The reasons were, of course, several whether it was improper political opinion or friends that were considered to be dangerous by the regime and so on. These translators couldn't therefore officially do their craft for a living and had to find another job. Since it was mostly men and women for whom literature was a life-long interest and passion they still pursued their dream to contribute to the enrichment of Czech culture despite the severe ban. So they continued to translate various titles, but they had to find so-called coverers. Using pseudonym did not help, because the regime had surveillance of these fake names. Banned translators had to find a man or woman who would lend them his or her name or in other words - identity. Coverer was thus the translator, who signed his name under somebody else's translation. With this person Odeon then signed a contract, sent letters to him, printouts and also royalties. The person's name appeared on the cover of the book, as well as on all promotional flyers and magazines. The only one having dealings with the actual translator of that book was the coverer. Coverers were from the principle of the matter brave and selfless people who wanted to help their less fortunate colleagues and were not afraid to take big risks [Rachůnková 1992: 5-8].

It would be really hard to try to find many people that had something to do with Odeon and they would not have any experience whatsoever with covering at least once, whether it was the actual covering of someone's translation or being covered by someone or just 
knowing about the process. But what many of them did not know was why some translators were banned from work. Often the banned translators themselves did not know this for sure. One of them was translator Rudolf Pellar. He talked about how both he and his wife were banned authors by the communist regime and they could not translate any books but in reality, didn't exactly know why that was the case.

Fortunately in those days, there were enough people who helped us and "covered" us by their names, so we could continue to translate. [...] One day the phone rang: "This is Honza Zábrana, I've not been to your place for a long time, are you at home?" At home we were so Honza came about an hour after that, he sat on a chair and said, "I have been offered some Hemingway, and that's your author. I have enough work right now, so I'll sign my name under it for you. [...] Of course, we were a little disappointed when our translation was published under another name. But we did not regret it so much, because for us the most important thing was always the work itself.' [Pellar 2008: 82-84]

The names of the banned translators were forwarded by phone-calls to the editors of various publishing houses so they would be known everywhere and would have no chance to find any work. Covering was, therefore, quite a common thing and a phenomenon at the same time because everything was done in secret but on a massive scale. Respondents are more often than not themselves unsure who else in Odeon knew about it. What's certain is that it's definitely never been fully revealed, which speaks about the character of the people employed in the publishing house. Even people in almost the highest positions in Odeon knew about it. In the case of Odeon, it was editor in chief himself who knew about covering, which was the most convenient for everyone involved because they had support in such a high-ranking individual. Editor in chief himself knew how things were, so even if the whole scam was uncovered the editor in chief managed to somehow come out of it without much of retribution. Even the editors weren't often aware that the editor in chief knew about the whole thing until he told them himself. All this shows that within Odeon worked a team of really dependable people who stuck together and did not betray each other. Thanks to this fact only these people could afford visiting the editorial office without any problems. Politics which largely interfered in the Odeon's editorial plan apparently had not the slightest control over the everyday events in the editorial office. Although the majority of the directors acted as state inspectors, the Odeon's editorial office was its own independent "world".

Covering, therefore, worked very well, but it had its risks and various problems. Translator and editor Josef Forbelský recalled that some translators were offended by the offer that they should hide behind the name of another translator. Another problem was mentioned by translator Dušan Karpatský when he said that Odeon at one time wanted to publish one of his translations but at the same time, he became a banned author by the regime. It was too late for a covering and the book could not be published so Karpatský was paid a severance pay from Odeon [Rubáš 2012: 89, 186]. Another type of a situation when covering was not needed was when a translation was published anonymously. Covering itself was criminal activity, and that's why coverers and those being covered could get into many problematic situations. It sometimes happened that the coverer was arrested for something or even died and Odeon's editors were worried that unfinished translation would be found at the person's home, so they sent someone from the editorial office for 
the manuscript. It should be stressed out once more what a group of people was working within the Odeon as well as how it was a generally known fact in the publishing house that some banned translators are being covered. Potential problems were numerous. Another thing that sometimes happened was that the coverer has received awards for the translation which he himself actually did not do. Sometimes coverer didn't want to accept an award for something he did not do and Odeon's editors had to persuade him to do it because in another case the secret could have gotten out [Heroldová-Štovícková 2009: 113]. Coverers were considered to be the authors of the translations and they were therefore interviewed or they were expected to know everything about that particular translation which could have been a major problem sometimes.

Finding a coverer was not an easy task. Translators willing to help fellow colleagues were many however they couldn't cover more people at once. It would be suspicious if the coverer published a large number of books within one year. Not only that but coverers had been actually working on their own translations so they could not afford to cover too much of other titles. All in all, there were many problematic and potentially dangerous situations but it did not discourage editors and translators from making a stand against the regime and trying to help their colleagues in need. Coverage was the most unselfish example of human conduct, in the context of this very topic, that one could possibly find at the Odeon or any other publishing house in general.

\section{Conclusion}

The normalization period is a term that is not easy to characterize comprehensively because at that particular time there was a constant change and evolution in society. In this ever-changing period, Odeon publishing house formed a kind of cultural constant. Odeon's editorial office had one goal, which at first glance seems very simple, and that was to familiarize Czech readers with the best foreign literature, both classical and modern. Odeon held onto this objective independently from the on-going political, social and other changes in the society. Editors in chief like Josef Čermák did everything they could to restrict the political influence in Odeon. This common goal of the whole editorial office and constant quarrels with the Ministry of Culture, often over ridiculously looking trifles, created a common enemy for the editorial office, which prevented them from their "mission" to spread literary culture. All of this in connection with the events of 1968 created within the editorial office a unique environment in its own way. This environment represents that "island of freedom" as it was thanks to this group of people that a phenomenon called covering was a possibility. All the former members of Odeon's editorial office fondly reminisce about this group of people and many of them remained friends till this very day. Odeon, therefore, represented for Czech readers an imaginary gateway to the world literature and culture itself. Readers got their hands on many important foreign titles, whether classical or new. For Odeon's employees themselves, publishing house represented something else. Of course, it was a cultural place where they discussed the latest news from the world of literature but it was also that certain "island of freedom" where the influence of politics was indeed noticeable but never to the point that it would disrupt the specific atmosphere that the editorial office had. It was the place where a number of very prominent and well-educated individuals worked who managed to stick together and focus on 
their main objective, which was the spread of foreign culture into our surroundings. But Odeon wasn't the "island of freedom" just for its employees but also for all the readers that had a chance to experience the pinnacle of foreign literary culture and that still to this day have many books published by Odeon in their personal libraries.

\section{Bibliography}

Čermák, Josef [2014]. Odeon - vstupní brána do světové literatury. Rozhovor vedl Vratislav Kozák.

Forbelský, Josef [2013]. Svět se mnou, svět beze mě. Prague: Academia.

Forstová, Eva [2013]. Knihy podle norem: kulturní instituce v systému řízené kultury. Státní nakladatelství krásné literatury, hudby a umění. Prague: Filozofická fakulta Univerzity Karlovy.

Halada, Jan [1993]. Člověk a kniha: úvod do nakladatelské specializace. Prague: Karolinum.

Halada, Jan [2007]. Encyklopedie českých nakladatelství 1949-2006. Prague: Libri.

Heroldová-Štovíčková, Věra [2009]. Po světě s mikrofonem. Prague: Radioservis, Osudy (Radioservis).

Holquist, Michael [2012]. Pokřivený originál: paradox cenzury. In. Pavlíček, Tomáš - Píša, Petr - Wögerbauer, Michael (eds.). Nebezpečná literatura? Antologie z myšlení o literární cenzuře. Brno: HOST, pp. 103-118.

Janáček, Pavel - Píša, Petr - Šámal, Petr - Wögerbauer, Michael, et al. [2015]. V obecném zájmu: cenzura a sociální regulace literatury v moderní české kultuře 1749-2014. Prague: Academia.

Klímová, Nikola (ed.) [2016]. České knižní obálky v edičních řadách: SNKHLU/Odeon 1953-1994. Prague: UMPRUM.

Müllerová, Beate [2012]. Cenzura a kulturní regulace: mapování terénu. In. Pavlíček, Tomáš - Píša, Petr Wögerbauer, Michael (eds.). Nebezpečná literatura? Antologie z myšlení o literární cenzuře. Brno: HOST, pp. 217-247.

Pavlíček, Tomáš - Píša, Petr - Wögerbauer, Michael (eds.) [2012]. Nebezpečná literatura? Antologie $z$ myšlení o literární cenzuře. Brno: HOST.

Pellar, Rudolf [2008]. Nejdřív se musite narodit... Prague: Radioservis, Osudy (Radioservis).

Pistorius, Vladimír [2003]. Jak se dělá kniha: př́ručka pro nakladatele. Prague: Paseka.

Přibáň, Michal [2014]. Česká literární nakladatelství: 1949-1989. Prague: Academia.

Rachůnková, Zdeňka [1992]. Zamlčovaní překladatelé: bibliografie 1948-1989. Prague: Ivo Železný.

Rataj, Jan - Houda, Přemysl [2010]. Československo v proměnách komunistického režimu. Prague: Oeconomica.

Rubáš, Stanislav [2012]. Slovo za slovem: s překladateli o překládání. Prague: Academia.

Steinová, Dagmar [2007]. Vzpomínání. Prague: G plus G.

Šámal Petr [2015]. V zájmu pracujícího lidu: Literární cenzura v době centrálního plánování a paralelních oběhů. In. Janáček, Pavel - Wögerbauer, Michael - Píša, Petr - Šámal, Petr, et al. V obecném zájmu: cenzura a sociální regulace literatury v moderní české kultuře 1749-2014. Prague: Academia, pp. 1099-1118, 1178.

Šustrová, Petruška [2008]. Služebníci slova. Prague: Pulchra.

Vaněk, Miroslav [2002]. Ostrůvky svobody: kulturní a občanské aktivity mladé generace v 80. letech v Československu. Prague: Votobia.

Wögerbauer, Michael [2012]. Úvodem. In. Pavlíček, Tomáš - Píša, Petr - Wögerbauer, Michael (eds.). Nebezpečná literatura? Antologie z myšlení o literární cenzuře. Brno: HOST, pp. 7-17.

Vratislav Kozák $\left({ }^{*} 1990\right)$ absolvoval magisterské studium na Katedře orální historie a soudobých dějin a v současnosti pracuje na svém doktorátu na Pracovišti historické sociologie $v$ rámci Fakulty humanitních studií Univerzity Karlovy. Odborně se mimo jiné zabývá sociálními dèjinami a dějinami novověku. 